УДК $341.1 / 8$

\title{
THE ROLE OF "SOFT LAW" IN RELATIONS OF STRATEGIC COOPERATION BETWEEN UKRAINE AND PRC: INTERNATIONAL LEGAL ANALYSIS
}

\section{РОЛЬ «М'ЯКОГО ПРАВА» (SOFT LAW) У ВІДНОСИНАХ СТРАТЕГІЧНОГО СПІВРОБІТНИЦТВА МІЖ УКРАЇНОЮ І КНР: МІЖНАРОДНО-ПРАВОВИЙ АНАЛІЗ}

\section{РОЛЬ «МЯГКОГО ПРАВА» (SOFT LAW) В ОТНОШЕНИЯХ СТРАТЕГИЧЕСКОГО СОТРУДНИЧЕСТВА МЕЖДУ УКРАИНОЙ И КНР: МЕЖДУНАРОДНО-ПРАВОВОЙ АНАЛИЗ}

\section{Smyrnova K.V.}

Doctor of Juridical Science, Professor at Institute of International Relations of Kyiv National Taras Shevchenko University. E-mail: ksenya.smyrnova@gmail.com

\section{Gandziura A.V.}

PhD. candidate of the Comparative and European Law Department of the Institute of International Relations of Kyiv National Taras Shevchenko University. E-mail: alisa_gandzjura@ukr.net

\section{Смирнова К.В.}

Доктор юридичних наук, професор Інституту міжнародних відносин Київського національного університету імені Тараса Шевченка. E-mail: ksenya.smyrnova@gmail.com

\section{Гандзюра А.В.}

здобувач кафедри порівняльного і європейського права Інституту міжнародних відносин Київського національного університету імені Тараса Шевченкаю. E-mail: alisa_gandzjura@ukr.net

\section{Смирнова К.В.}

доктор юридических наук, профессор Института международных отношений Киевского национального университета имени Тараса Шевченка. E-mail: ksenya.smyrnova@gmail.com

\section{Гандзюра А.B.}

соискатель кафедры сравнительного и европейского права Института международных отношений Киевского национального университета имени Тараса Шевченка. E-mail: alisa_gandzjura@ukr.net

Abstract. The article deals with peculiarities of the soft law functioning in regulation principles formation of bilateral strategic cooperation between Ukraine and China. The weight and influence of the "soft law" provisions in the context of the legal and regulatory framework of bilateral relations between the countries have been summed up. A deep and profound analytical assessment of various bilateral agreements has been done. Different types of legal norms are being characterized from the point of their legal obligation and the advantages and disadvantages of their application in the agreements in view of current world trends. The survey shows that serving as a regulator of relations, "soft law" may entail certain legal consequences. First of all, it can be the basis for a document that is legally binding source of law, in addition, the rules of "soft law" are able to independently regulate social relations, complementing the official source of law or filling its gaps.

Keywords: international law, soft law, strategic cooperation, legal norm, international treaty, Ukraine, China.

Анотація. Стаття розкриває особливості застосування "м'якого права» ("soft law”) у формуванні засад регулювання двостороннього стратегічного співробітництва між Украйною і КНР. Проаналізовано фактичне застосування норм і формулювань «м'якого права», їх роль і вплив в системі нормативно-правової бази двосторонніх 
відносин між країнами. Різні види правових норм характеризуються з огляду на їх юридичну обов'язковість та переваги і недоліки їх застосування беручи до уваги сучасні світові тендениії. Проведено глибоку й детальну аналітичну очінку різних двосторонніх угод. Надається характеристика різних видів правових норм, з точки зору їх правової обов 'язковості, а також переваг та недоліків їх застосування в угодах з урахуванням поточних світових тенденщій. Розвідка показує, що виступаючи регулятором відносин "м'яке право» може спричинити певні правові наслідки. Поперше, воно може стати основою для документа, який є юридично обов'язковим джерелом права, крім того, положення «м'якого права» здатні самостійно регулювати суспільні відносини, доповнюючи офічійне джерело права або заповнюючи його прогалини.

Ключові слова: міжнародне право, «м'яке право», стратегічне співробітниитво, правова норма, міжнародний договір, Украйна, Китай.

Аннотация. Статья раскрывает особенности применения «мягкого права» ("soft law”) в формировании приниипов регулирования двустороннего стратегичесого сотрудничества между Украиной и КНР. Проанализировано фактическое применение норм и формулировок "мягкого права», их роль и влияние в системе нормативноправовой базы двусторонних отночений между странами. Разные виды правовых норм характеризуются с позиции их юридической обязательности, а также преимущества и недостатки их применения, учитывая современные мировые тендениии. Проведена глубокая и детальная аналитическая оченка разных двусторонних соглашений. Предоставляется характеристика разных видов правовых норм, с точки зрения их правовой обязательности, а также преимуществ и недостатков их применения в договорах с учетом современных мировых тенденций. Анализ показывает, что выступая регулятором отночений "мягкое право» может приводить к опредленным правовым последствиям. Во-первых, оно может стать основой для документа, который будет юридически обязатльным источником права, кроме того, положения «мягкого права» способны самостоятельно регулировать сочиальные отночения, дополняя офиџиальный источник права или заполняя его пробельл.

Ключевые слова: международное право, «мягкое право», стратегическое сотрудничество, правовая норма, международный договор, Украина, Китай.

Research problem setting. In the diversity of international relations there is a group of states, which possess a certain priority. To characterize the development of such relationships and in order to distinguish them from relations with other subjects of international life, the definition of "strategic partnership" was used [Herasymchuk, 2014: 4]. The issue of legally binding provisions in bilateral agreements and the regulation approach of such relations appears urgent. While researchers have reached a certain agreement on determining the sources of the rules of law, the issue of binding legal effect recognition creates numerous discussions, indicating that the chosen topic is becoming of current interest and the need for further study.

The aim of the article is to analyze the content of the "soft law" phenomenon and the feasibility and prospects of its application in strategic cooperation between Ukraine and PRC.

Analysis of the latest researches and publictions. Various aspects of UkrainianChinese relations evolution were highlighted in works of such outstanding scientists as V. Urusov, V. Sednev, S. Pron, I. Pogorelova [16] and others, while V. Shamraeva, V. Gerasymchuk, V. Kiktenko [15], G. Gulevska focused their researches on a deeper and more profound understanding of strategic partnership as a new model of international relations. All these precious investigations could be organically combined with studies of the legal nature 
"soft law" norms. These were undertaken by such well-known scholars as R. Bekster, D. Trubek [10], H. Hillgenberg, F. Snyder [8], I. Shalinska [17], V. Butkevych, V. Mytsyk, O. Zadorozhnii, K. Smyrnova [7, 18], O. Demin [20], A. Rykova [21] and other prominent scientists.

Taking into account recent and developing changes on the path towards efficient Ukrainian-Chinese bilateral strategic cooperation it is important to conduct a multidimensional investigation of the issue.

Basic research material. In recent decades, strategic partnership has become a major leverage in understanding the bindings and obligations between states. Obtaining a privileged status of strategic partnership with strong global players is an indirect means of demonstrating its importance on the international scene. The use of this concept goes beyond mere cooperation between countries, but rather points to a more global and systematic reconfiguration of the international relations development [Kiktenko, 2013: 4]. Therefore, the intensification of Ukrainian-Chinese relations becomes of key importance in the foreign policy strategy of our country in the context of current dynamic realities.

The parties see mutual benefit in cooperation and show interest in using each other's resources for common goals, which is reflected in the relevant agreements. Analyzing bilateral agreements within the framework of the declared strategic cooperation between states, it is apparent that the parties generally do not rush to declare the legal formalization of closer relations, which can lead to serious consequences and responsibilities [Herasymchuk, 2014: 2].

While "soft law" has drawn increasing attention in recent years, it has not received uniform support and got significant attacks on its use in various settings. It covers those weak provisions of international agreements (and acts) not entailing obligations. A soft law instrument might not seem to introduce new legal obligations, it might promote a very radical interpretation of an obligation provided in a "pure" legal act. This large variety of effects shows that soft law matters and has important practical and legal consequences for institutions, Member States or individuals. Indeed, one can envisage that in the absence of the soft law instrument, the national or European authorities might interpret the specific obligation provided in the hard law provision in a more lenient or indeed more stringent way [7].

Objections to the use of "soft law" include lack of clarity and precision needed to provide predictability and a reliable framework for action; treaties include "hard" law provisions that enshrine market principles and these can only be offset if equally "hard" provisions are added to promote social objectives; "soft law" is a device that is used to have an effect but it by-passes normal systems of accountability; "soft law" undermines the legitimacy because it creates expectations but cannot bring about change. However, among the critiques of "hard" law one finds the following observations: "hard law" tends toward uniformity of treatment while many current issues demand tolerance for significant diversity among the states; "hard law" presupposes a fixed condition based on prior knowledge while situations of uncertainty may demand constant experimentation and adjustment; "hard law" is very difficult to change yet in many cases frequent change of norms may be essential to achieve optimal results, etc [Trubek, Cottrell, Nance, 2005: 3].

Most of the proclaimed strategic partnerships have declarative nature. Among the most commonly used forms of documents there are memorandums, declarations and charters general documents that do not define specific areas of cooperation and do not include detailed plans for their implementation [Zarembo, 2010].

Use of "hard law" instruments plays a particularly important role in securing cooperation because it hedges against the mistrust that characterizes the anarchic international environment. Legally binding rules deter potential violations because actors are more likely to factor in such disincentives as reputation costs, issue linkage, reciprocity, and the shadow of the future into their calculus of whether or not to remain in compliance. In addition, hard law often forces actors to consider the threat of sanctions [Trubek, Cottrell, Nance, 2005: 9]. 
This may lead to postponement of initial establishment of bilateral relations. Therefore the current peculiarity of an increase in the role and significance of acts that are not formally and legally binding, but have a significant impact on the formation of international legal norms and practice of international relations, is worth noting here. For the definition of such acts, various terms are being used, for example, "non-treaty agreements", "program law", "informal instruments", "international documents without official status" or "unofficial international acts", "green law", "sub-law", "imperfect law", "quasi-right", "non-right", "nonstandard norms" etc., but the most common and applicable one is "soft law" [Hulievska, 2017: 248].

"Soft law" is a very general term, and has been used to refer to a variety of processes. The only common thread among these processes is that while all have normative content they are not formally binding. Francis Snyder describes "soft law" as "rules of conduct which in general have no legally binding force but which nevertheless may have practical effects."

It's worth noting that "soft law" is better equipped to promote cooperation while preserving sovereignty. It allows states to adapt their commitments to their particular situations rather than trying to accommodate divergent national circumstances within a single text. The greater flexibility of non-binding legal instruments allows for renegotiation or modification of agreements as circumstances change [Trubek, Cottrell, Nance, 2005: 12].

The underlying reason is that subjects may not have the primary intention of concluding an international agreement and therefore do not provide a document with the appropriate form. Or the subjects do not want to establish clear rights and obligations for themselves, but they intend to put down on paper a certain level of relations between them [Buromenskyi, 2006: 51].

As a result, various "soft law" instruments used by countries in bilateral cooperation can be singled out: unilateral general acts (communiqués, multi-annual programs), bilateral general acts (joint declarations), sectoral bilateral acts (Memorandum of Understanding, administrative agreements), and sectoral agreements.

The analysis of current international treaties, which constitute the contractual basis of bilateral relations between Ukraine and China, can be carried out taking into account their classification according to different classical criteria, but the general tendency is a gradual and phased transition from the prevalence of "soft law" to the enaction of specific agreements and commitments considering legally binding norms of treaties.

Agreements that were formed at the stage of laying the foundations of the bilateral cooperation are generally framework agreements on political issues, which determined the overall course of bilateral international relations between Ukraine and the PRC and framework sectoral agreements of general content. Among the basic documents, in a point of fact, we should mention the Joint Communiqué on the establishment of diplomatic relations between Ukraine and the People's Republic of China (04.01.92) [3] and the Memorandum of Understanding to the Communiqué, the Joint Ukrainian-Chinese communiques (31.10.92 and 24.06.95) [4], the Joint (Kiyv) Declaration between Ukraine and the People's Republic of China (06.09.94) [2], the Declaration on development and intensification of friendship and cooperation between Ukraine and the People's Republic of China (04.12.95) and other agreements which incorporate the penchant of their norms for the "soft law" instruments. Most of cases in these documents do not stipulate legal provisions that create specific rights and obligations of the parties, but determine the general scope of the contract.

For these agreements the following wording is typical: "the parties expressed their readiness to continue to work together," "the parties reached a common ground," etc [4], which are intended to lay the foundations of friendship and consolidate the common views and interests, as well as the commitment to the basic general principles of international law.

The use of "soft law" in early stages of bilateral relations establishment is logical and convenient, since a greater flexibility of recommendatory legal instruments leaves the possibility of subsequent discussion and modification of arrangements under new conditions. 
A distinctive feature of "soft law" acts is their existence on the verge between legal norms and norms of a moral and political nature [Shalinska, 2013: 56] which is reflected in the provisions of the above-mentioned agreements, that stipulate, in particular, the readiness of the parties "to develop friendship and cooperation between the two countries based on the principles of peaceful coexistence, mutual respect for sovereignty and territorial integrity, mutual non-hostility, non-interference in the internal affairs of each other, equality, mutual benefits, as well as peaceful settlement of disputes" [3].

Each of the founding documents reflects the next step on the path to cooperation and contains provisions that reflect the general position of the parties on the current situation in the relationships. These documents contributed to the principles harmonization of the Ukrainian-Chinese relations development on the basis of recognition of mutual sovereignty, the establishment of consular relations and the potential transition to a diplomatic level.

We recognize that the question is not necessarily one of "hard" versus "soft law": there is also the issue of the possible interaction between these two approaches to governance and thus of "hybrid" constellations in which both "hard" and "soft" processes operate in the same domain and affect the same actors [Trubek, Cottrell, Nance, 2005: 3].

The development of bilateral relations leads to the legal forms modification and the deepening and improvement of contractual framework. The desire to strengthen trade and economic relations and active cooperation in this field opened a new stage in the establishment of contractual relations between Ukraine and the People's Republic of China. It is at this stage that we see a gradual transition from the general principles outline of cooperation to the specification of the agreements.

The Agreement between the Government of Ukraine and the Government of the People's Republic of China on trade and economic cooperation (of 08.08.1992) was the first official document which stipulated the parties' agreement to take all necessary measures to promote the continuous and stable development of trade-economic relations between the two countries on an equal and mutually beneficial basis. It contained "hard" legal provosions in presence of a wide range of "soft law" instruments.

The document provides for the mutual assistance of the most favored nation regime with regard to the collection of export and import duties for both countries, other fees, and customs formalities. The parties also agreed to encourage investments in the territory of the other party [5].

In this way we can see, that instruments of "hard" law and "soft" law can be combined sequentially as mutually reinforcing complements to lead to greater international cooperation [Shaffer, Pollack, 2010: 707].

On October 14, 2003, three documents were signed which regulate specific issues and processes in the field of economic cooperation and trade and indicate the establishment and intensification of processes in this area - these are the Memorandum of the 8th Meeting of the Intergovernmental Ukrainian-Chinese Commission on TEC, the Agreement between the State Export Control Service of Ukraine and the Ministry of Commerce of the People's Republic of China on the use of import certificates and a Memorandum of Understanding between the State Export Control Service of Ukraine and the Ministry of Commerce of the People's Republic of China on the establishment of cooperation in the field of export control.

This cooperation envisages, first of all, the exchange of information and documentation and aims to establish long-term cooperation in the field of high technology and trade in goods which are a subject to export control, ensuring strict compliance with relevant international norms and rules [1].

Signing of the Protocol between Ukraine and China on access to the markets of goods and services within the framework of Ukraine's accession to the WTO on December 16, 2005, was a significant step for Ukraine and has become one of the greatest achievements of the whole negotiating process on the way of our country to the WTO. 
The Treaty on Friendship and Cooperation between Ukraine and the People's Republic of China of December 5, 2013 is an agreement of great significance - the basic political document, which was under discussion for almost 15 years. For the first time in history of our bilateral relations, a legally binding document has been signed, which defines key principles and establishes the foundations for the further development of the Ukrainian-Chinese strategic partnership. This document represents a totally new step in relations, characterized by the prevalence of "hard" law and the presence of specific legally binding rules.

The fact of ratification of such document itself for the term of 25 years with automatic prolongation for the next five-year periods in the absence of parties' intentions to terminate its action indicates the readiness of both sides to put specific agreements and cooperation into action. The formulation of norms gradually departs from general and neutral phrases and "soft" law concepts. The preamble, articles 1 and 9 of the Treaty contain a clear wording "strategic partnership relationship", Article 2 provides the wording "parties undertake" regarding non-use of force or threat of its use and peaceful means of disputes resolution, and Article 6 contains provisions that both of the Contracting Parties "do not allow" any kind of encroachments on the sovereignty, security or territorial integrity [6].

The Joint Declaration of Ukraine and the People's Republic of China on the further deepening of the strategic partnership relations and the Program of Development of the Strategic Partnership between Ukraine and the People's Republic of China for 2014-2018 identified the specific directions and areas of practical cooperation and implementation of joint projects for this period for the first time in the history of bilateral relations [Honcharuk, Hobova, Kiktenko, Koval, Koshovyi, 2016: 18].

Conclusion. Partnership establishment on today's world scene is a rather multifacet process that requires unconventional approaches, but it is worth noting that it is possible to achieve a high partnership level with the help of a set of measures, aimed at developing long term cooperation. It is necessary to take into account the awareness of the needs of each party, which leads to interaction. Cultural peculiarities of the partner countries are also undoubtedly an important factor in establishing and evolution of stable and flourishing relations. These factors need adjustment of global strategy, approaches and the use of diverse legal tools.

Therefore, serving as a regulator of relations, "soft law" in the end may entail certain legal consequences. First of all, it can be the basis for a document that is legally binding source of law, in addition, the rules of "soft law" are able to independently regulate social relations, complementing the official source of law or filling its gaps [Demin, 2016: 76].

"Soft law" comes in many varieties and the choice between "hard" and "soft" law is not a binary one. Different domains have different needs, and "hard" and "soft" legal processes come in many different shapes and forms.

\footnotetext{
References

1. Меморандум про взаєморозуміння між Державною службою експортного контролю України і Міністерством комерції Китайської Народної Республіки щодо налагодження співробітництва в галузі експортного контролю від 14 жовтня 2003 p. [Memorandum of understanding between the State Export Control Service of Ukraine and the Ministry of Commerce of the People's Republic of China on the establishment of cooperation in the field of export control, 14 October 2003], $<$ http://zakon5.rada.gov.ua/laws/show/156_046>

2. Спільна декларація України і Китайської Народної Республіки від 6 вересня 1994 p. [Joint Declaration of Ukraine and the People's Republic of China, 6 September 1994], <https://zakon5.rada.gov.ua/laws/show/156_004>

3. Спільне комюніке про встановлення дипломатичних відносин між Китайською Народною Республікою і Україною від 4 січня 1992 p. [Joint Communique on the establishment of diplomatic relations between the People's Republic of China and Ukraine, 4 January 1992], <http://zakon2.rada.gov.ua/laws/show/156_006>
} 
4. Спільне комюніке за підсумками офіційного візиту в Україну Прем'єра Державної Ради Китайської Народної Республіки Лі Пена від 25 червня 1995 р. [Joint communique on the basis of the State Council Prime Minister of the People's Republic Li Pen official visit to Ukraine, 25 June 1995], <https://zakon5.rada.gov.ua/laws/show/156_058>

5. Угода між Урядом України і Урядом Китайської Народної Республіки про торговельне-економічне співробітництво від 8 серпня 1992. [Agreement between the Government of Ukraine and the Government of the People's Republic of China on trade and economic cooperation, 8 August 1992], <http://zakon5.rada.gov.ua/laws/show/156_008>

6. Закон України Про ратифікацію Договору про дружбу і співробітництво між Україною і Китайською Народною Республікою від 15 травня 2014 р. [The Law of Ukraine On Ratification of the Treaty on Friendship and Cooperation between Ukraine and the People's Republic of China, 15 May 2014], $<$ http://search.ligazakon.ua/1_doc2.nsf/link1/T141271.html>

7. Smyrnova K., Korynevych A., Kostyuchenko Y., Berezovska I., Fedorova A. (2018) Paths of legal perspective of the soft law concept within international and European Union law. Herald National Academy of Managerial Staff of Culture and Arts, 2(2): 201-206

8. Snyder F. (1993) Soft law and institutional practice in the European Community. European University Institute Working Paper, LAW. Florence, No. 93/5.

9. Shaffer, Gregory C., Pollack, Mark A., (2010) Hard vs. Soft Law: Alternatives, Complements and Antagonists in International Governance (June 26, 2009). Minnesota Law Review, Vol. 94, pp. 706-99; Minnesota Legal Studies Research Paper No. 09-23, $<\mathrm{https}: / /$ ssrn.com/abstract $=1426123>$

10. Trubek D.M., Cottrell P., Nance M. (2005) "Soft Law," "Hard Law," and European Integration: Toward a Theory of Hybridity, $<$ https://law.wisc.edu/facstaff/trubek/hybriditypaperapril2005.pdf $>$

11. Буроменський М.B. (2006) Міжнародне право: Навч. посібник [International Law: Teaching manual]. Київ: Юрінком Інтер, 336 с., <https://lawbook.online/regulirovaniepravovoe-mejdunarodnoe/mijnarodne-pravo-navch-posibnik-yurinkom-inter.html >

12. Герасимчук В.Г. (2014) Стратегічне партнерство: принципи, інструментарій, ефективність [Strategic partnership: principles, tool, efficiency]. Економічний вісник Начіонального технічного університету Украйни "Київський політехнічний інститут», 11: 61-66. < http://nbuv.gov.ua/UJRN/evntukpi_2014_11_12>

13. Гончарук А.З., Гобова Є.В., Кіктенко В.О., Коваль О.А., Кошовий С.А. (2016) Аудит зовнішньої політики: Україна-Китай. Дискусійна записка, [Foreign Policy Audit: Ukraine-China. Discussion note], <http://www.irf.ua/content/files/dp-2016-40.pdf>

14. Гулєвська Г.Ю. (2017) Норми «м'якого права» (soft law) у регулюванні міжнародних економічних відносин [Soft law standards in the regulation of international economic relations], <http://pap.in.ua/3_2017/75.pdf>

15. Кіктенко В.О. (2013) Східний вектор стратегічного партнерства України в умовах глобального світу. Аналітична доповідь [Eastern vector of strategic partnership of Ukraine in the global world. Analytical report] Київ: Інститут Сходознавства ім. А.Ю. Кримського НАН України, 184 с., <http://oriental-studies.org.ua/wpcontent/uploads/2016/01/978-966-02-6993-4.pdf>

16. Погорєлова I.C. (2009) Україна і країни Східної Азії: політичний вимір сьогодення [Ukraine and the countries of East Asia: the political dimension of the present] Наукові праиі [Чорноморського державного університету імені Петра Могили]. Сер.: Політологія 109: 127-132.

17. Шалінська I.В. (2013) Акти «м'якого права» та міжнародний правопорядок ["Soft law" acts and international legal order] Науковий вісник Міжнародного гуманітарного університету. Сер.: Юриспрудениія №6-2 vol 1: 55-57. 
18. Смирнова К.В. (2012) Концепція «м'якого» права (soft law) в міжнародному праві та праві Свропейського Союзу [The concept of "soft law" in international law and the law of the European Union], <http://www.jusintergentes.com.ua/archives/2012/3/18.pdf>

19. Зарембо К. (2010) Стратегічні партнерства без стратегії, або чому цей інструмент не працює на користь України [Strategic partnerships without strategy, or why this tool does not work in favor of Ukraine], <https://day.kyiv.ua/uk/article/panoramadnya/strategichni-partnerstva-bez-strategiyi>

20. Демин А.В. (2016) «Мягкое право» в эпоху перемен: опыт компаративного исследования ["Soft law" in an era of change: the experience of comparative research]. Москва: Проспект, 240 с.

21. Рыкова A.A. (2016) Акты soft law в современном правовом регулировании [Acts of soft law in modern legal regulation], <http://xn----7sbbaj7auwnffhk.xn-p1ai/article/19789>. 